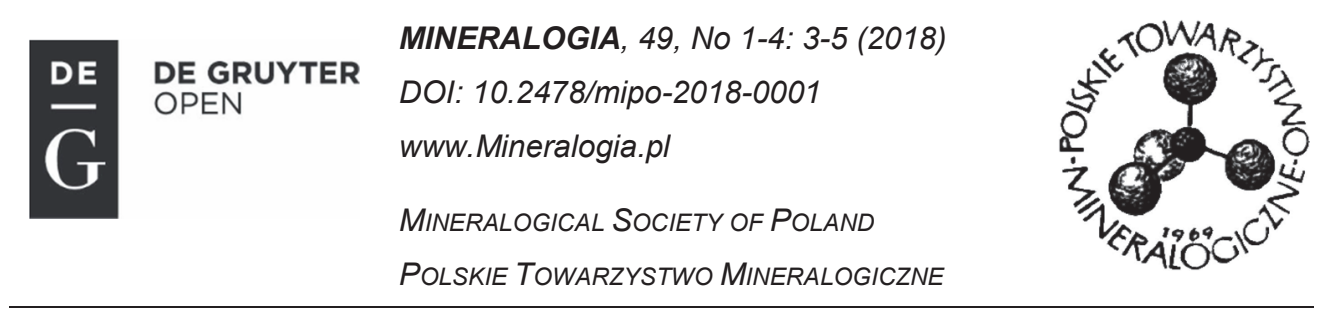

Printed in 2018

\title{
Jiři Konta (1922-2017)
}

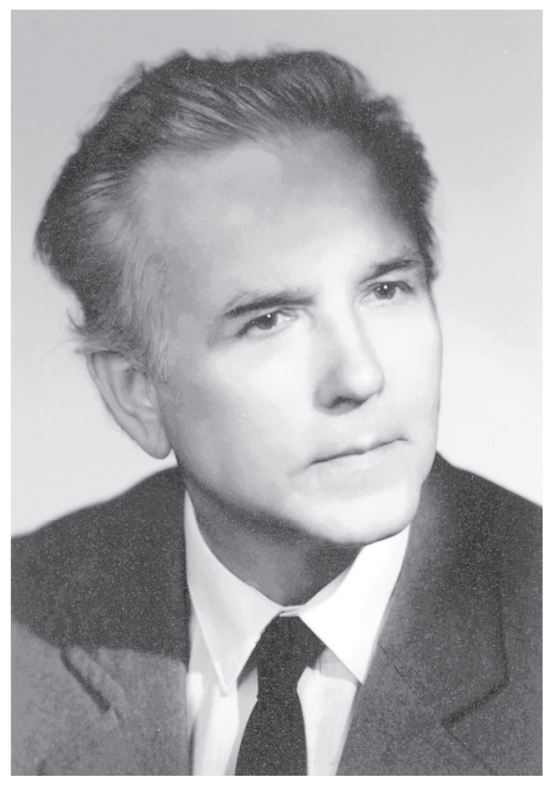

On the 22nd February 2017, Professor RNDr. Jiři Konta DrSc. died at the age of 95 . He was an Honorary Member of the Mineralogical Society of Poland. A world-renowned scientist in argillology, he was a member of many international- and Czech scientific organizations and a member of the editorial boards of several professional journals.

Jiři Konta was born on the 15th February 1922 in Žleby (eastern Bohemia). In this small, scenic locality at the foothill of Železné hory (Iron Mountains), he could admire the beauty of nature already as a young boy, beauty that later awakened a desire to study the Earth sciences at a university level. After completing primary school in Žleby in 1934, he started further education at a secondary school in nearby Č́slav. At that time, he joined the scout movement which gave him more opportunities to spent free time in harmony with nature. Unfortunately, all of this was brutally interrupted with the Nazi Germany annexation and partition of Czechoslovakia in 1938-39. Scouting activities were banned in 1939. Despite inhibiting regulations, Jiři Konta managed to complete his secondary school in 1942. As for many people in occupied Europe, he had to work in Germany as a forced labourer before, having been accused of continuing scouting activities, he was sent to a concentration camp in Mauthausen at the end of 1943. Despite extremely harsh camp conditions, Jiři Konta survived to see the camp liberated by US Army units on the 5th May 1945.

Immediately after the war, Jirri Konta studied geology in the Faculty of Natural Sciences at the Charles University in Prague from 1945-48 under the guidance of Professor Josef Kratochvil. He graduated with the degree of Doctor of Natural Sciences (RNDr. in Czech). He obtained the further titles of CSc. in 1956 and DrSc. in 1961. He was nominated an Associate Professor in 1952 and a Professor in 1961. At the beginning of the 1950s, Jiři 
Konta had already become interested in questions concerning clay matter, various aspects of which were to remain the focus of his future professional activities. The scope of these included the petrology of sedimentary rocks, the mineralogy, geochemistry and petrology of clay rocks, mineral raw materials used in the ceramic and glass industries and laboratory methods of investigating minerals and rocks. All were component parts of clay science which Professor Konta brought together in the term argillology.

At the turn of 1950s, he established cooperation with other eminent scientists actively investigating clay problems, among others, the Russian I.I. Ginzburg, the Americans R.E. Grim, W.D. Keller, W. Bradley, H. Murray and J. White and the German E.T. Degens. As a result, Professor Konta delivered many lectures at international conferences and spent several long-term visits abroad, e.g., in the US and Germany. During the academic year 1965/1966, he was a visiting professor at the University of Illinois, at the State College Pennsylvania, at Penn State University and at the Woods Hole Oceanographic Institute. Long-standing collaboration with German colleagues between 1980-89 guided by Professor E. Degens (University of Hamburg) focused on the investigation of the fine-grained clay material transported by the largest rivers of the world.

The Polish connections of Professor Konta began with a scientific excursion to Poland in 1974 which led to close collaborative contacts with a group of clay mineralogists in Warsaw, namely, Profesors K. Szpila and A. Wiewióra, and with Professor L. Stoch in Cracow. This collaboration was reflected in the conferring of the the title Honorary Member of the Mineralogical Society of Poland on Professor Konta in 1983. His interest in the practical and technological aspects of clay materials was expressed by his taking part, e.g., in the first conference POLSKA CERAMIKA (Polish Ceramics) held in Opoczno/Spała in 2000 .

Professor Konta was an organizer of several Czechoslovak conferences on the Mineralogy and Petrology of Clays. He was invited to cooperate with many foreign- and domestic scientific associations and professional journals. In 1981, he was elected President of the European Clay Groups. The crowning of his multi-faceted career was his election as President of the AIPEA (L'Association Internationale pour l'Etude des Argiles), a position he held from 1985-89. On his initiative, the journal Applied Clay Science was established, a journal which rapidly gained recognition and a high rank within the community of specialists dealing with the applicative aspects of clay materials.

Professor Konta was an author and co-author of so many papers that it would be impossible to list even the most important of them in this brief note. The record of his papers published prior to 2006 includes over 250 entries (see Acta Geodynamica et Geomaterialia 3, 2006, No.4). The following years brought more works, notably a wide and penetrating autobiography, The Beat of my Heart, published in the journal Clays and Clay Minerals in 2016.

Professor Konta also authored and co-authored many books: 1 . Horninotvorné minerály (with B.Hejtman), 1953; 1959; 2. Jilové minerály Československa, 1957; 3. Imbibometrie, 1962; 4. Kvantitativní system reziduálních hornin, sedimentů a vulkanoklastických usazenin; 1973; 5. Geochemie, 1980 (three chapters, ed. V.Bouška et al.); 6. Keramické a sklářské suroviny, 1982; 7. Slyšet své srdce, 2016.

The list of the accomplishments presented above is highly selective and represents only fragments of Professor Konta's achievements. They were appreciated and recognized in 
many ways, for instance, by his mother university (Charles University in Prague) that, in 1982, conferred the prestigious Božicki medal on him.

Professor Konta was a scientist of great caliber and a person of many talents, not limited to Earth sciences. He was, for instance, a gifted drawer. His kind and cheerful personality remains in the memories of all of us who knew him. We learned of his passing with a deep and heartfelt sorrow.

Piotr Wyszomirski 